\title{
Imagens e palavras no tecido de memórias tortuosas: Fazenda Modelo: novela pecuária em tempos de golpe
}

\author{
Mírian Sumica Carneiro Reis*
}

No dia $1^{\circ}$ abril de 1964 instaurava-se no Brasil o regime civil-militar de governo. Para os militares que tomaram o poder tratava-se da "revolução", antecipada, sobretudo nos documentos oficiais, para a noite de 31 de março. É que, no Brasil, e em boa parte do Ocidente, $1^{\circ}$ de abril é considerado o dia da mentira. A "revolução militar" e todas as suas consequências passariam até por piada de mau gosto, mas foram uma verdade duradoura e cruel, que se manteve por mais de vinte anos e repercute ainda hoje, sobretudo para aqueles vitimados pelas atrocidades do regime. Se, por um lado, o panorama político e econômico pareceu superar as mazelas de tão prolongada ditadura; os efeitos subjetivos, por outro lado, ainda são latentes.

Depois que o general Costa e Silva assume a presidência, em 1967, a repressão aos opositores, indiscriminadamente denominados de subversivos, ganha toda a violência, sobretudo depois de decretado o Ato Institucional 5, ou AI-5 como ficou popularmente conhecido, em dezembro de 1968. Decretado numa sexta-feira 13, em dezembro de 1968, aquele Ato, mais do que de mau augúrio para um dia em que a superstição determina como pressagioso, foi nefasto. O Brasil entrou em estado de exceção por tempo indeterminado, e, por isso, o presidente tinha autonomia para tomar decisões sem apreciação judicial. O Congresso entrou num recesso forçado, mandatos parlamentares foram cassados, os direitos políticos dos cidadãos foram suspensos e a censura se institucionalizou como instrumento do poder.

Com o AI-5, o regime escancarou suas intenções. Até aquele momento, os movimentos de combate ao governo e as tentativas de guerrilha armada urbana e rural eram reprimidas com violência, mas o seu saldo de mortos e desaparecidos era sonegado. A máquina do estado criou uma forte propaganda anticomunista, sobretudo no governo Médici, para aterrorizar a população, aliada às estratégias alienantes de divulgação do Milagre Econômico e à censura prévia. Foi assim até 1985, com um longo período de endurecimento, os chamados anos de chumbo, até a falência do regime e paulatina abertura a partir de 1974, quando Ernesto

Doutora em Ciência da Literatura (Teoria Literária) e professora da Universidade da Integração Internacional da Lusofonia Afro-brasileira (Unilab), Redenção, CE, Brasil. E-mail: miriansumica@unilab.edu.br 
Geisel assume a presidência. Ainda assim, no governo Geisel, o desaparecimento de presos políticos atinge seu ápice, e já não havia uma preocupação em simular tiroteios para justificar os mortos, situações desmentidas por autópsias e perícias. Segundo Elio Gaspari:

O sumiço dos cadáveres era uma resposta à estratégia do estorvo. Cortava caminho às denúncias baseadas em autópsias ou em testemunhos de moradores das localidades onde os DOIs [Destacamentos de Operações de Informaçãoes] inventavam tiroteios. Em 1964, morreram dezenove pessoas, mas apenas duas desapareceram. Em 1969, os oficiais da Operação Bandeirante sumiram com o cadáver de Virgílio Gomes da Silva, o comandante militar do sequestro do embaixador americano Charles Burke Elbrick. Nos anos seguintes o número de desaparecidos cresce, até que, em 1973, os dois números aproximam-se (GASPARI, 2003, p. 388). ${ }^{1}$

Como falar do medo com o medo das consequências? Como falar do horror com a sutileza de evitar que este mesmo mal lhe bata à porta (leia-se, arrebente tramelas e amarras, de portas, lares, corpos)? Em 1972, Renato Tapajós já havia sido preso e processado por ter escrito, na cadeia, o seu romance Em câmara lenta. Fernando Gabeira só lançaria o seu famoso O que é isso, companheiro? em 1979, ano da anistia, quando centenas de exilados puderam voltar ao Brasil. Feliz Ano Novo (1975), de Rubem Fonseca, e Zero (1975), de Ignácio de Loyola Brandão, foram cassados e apreendidos quase depois de um ano de publicados e permaneceram proibidos por aproximadamente dez anos.

A censura, fortalecida com o Ato Institucional $\mathrm{N}^{\circ}$, amordaçava intelectuais e artistas de todos os setores, da música ao teatro, do jornal impresso à televisão. Seguindo ainda a alegoria animal, mote da escrita em Fazenda Modelo, talvez a situação mais emblemática do povo brasileiro desde 1968, ano do AI-5, fosse a representação já clicherizada dos "macacos da sabedoria" (FIGURA 1): o melhor era não ver, não falar, não ouvir, mesmo que o silêncio forçado pudesse representar, num contexto político tão tenso, o consenso tácito com o regime.

O recorte pinçado da história, fundamental para a leitura de Fazenda Modelo, é o da relação entre cultura e censura. Depois do AI-5, era proibido, inclusive, denunciar a existência da censura. Veículos de comunicação liberais, que num primeiro momento apoiaram aberta ou tacitamente o regime, também foram alvo das lupas do censor. Segundo Flávio Tavares:

Júlio de Mesquita Filho e, em 1969, após sua morte, Júlio de Mesquita Neto e Ruy Mesquita deram, então, o melhor exemplo dessa rebelião liberal quando O Estado de S. Paulo e o Jornal da Tarde desafiaram a censura.

\footnotetext{
Ainda segundo Gaspari (2003, p. 389): "O número de desaparecidos de 1973 é impreciso. Os comandantes militares nunca reconheceram as datas das execuções praticadas no Araguaia. Assim, em vez de 28 , podem ser 30 ou 32. Nesse caso, baixa o número de desaparecidos de 1974" (nota do autor).
} 
Em vez de substituir a verdade das notícias cortadas pelos censores com a versão mentirosa inventada pelo governo militar, já que nenhum jornal podia circular com espaços em branco (a ameaça era fechamento sumário), eles começaram a publicar os cantos de Os Lusíadas, de Camões, ou insípidas receitas de cozinha, da primeira à última página, mostrando que ali estavam informações censuradas (TAVAREs, 2012, p. 39).

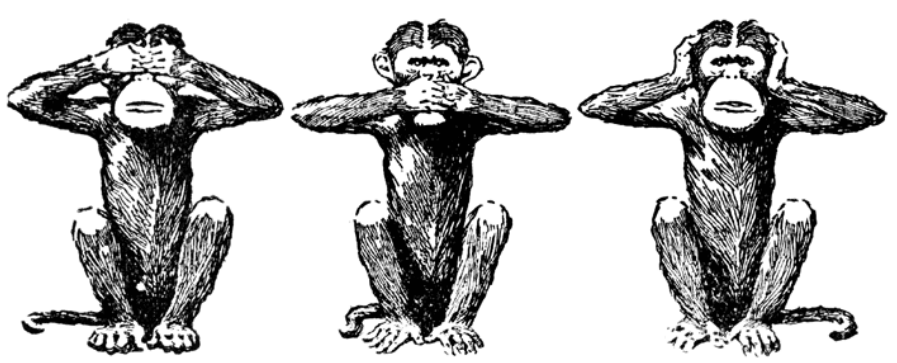

Fig. 1 - "Os macacos da sabedoria”. Nos anos de chumbo, para a maioria da população brasileira, o melhor era "não ver, não falar, não ouvir". Fonte: Blog Língua Ferina ${ }^{2}$

No fornal do Brasil, seu editor-chefe Alberto Dines decidiu usar metáforas para falar da censura que o jornal sofria e do recrudescimento da violência que o Ato Institucional n. 5 representava. Assim, no dia 14 de dezembro, os leitores mais atentos notaram uma mudança de tom, com um editorial cheio de jargões futebolísticos e de clichês, e, para maior estranhamento geral, uma previsão de tempo que, apesar de errar completamente na análise meteorológica, previa um período vindouro sombrio. Zuenir Ventura relembra esse episódio:

Apesar do sol de dezembro, por exemplo, a previsão meteorológica anunciava no alto à esquerda da primeira página: "Tempo negro. Temperatura sufocante. $\mathrm{O}$ ar está irrespirável. O país está sendo varrido por fortes ventos”. No outro lado da página, aparecia em destaque uma irrelevância: "Ontem foi o dia dos cegos". A foto principal era de Costa e Silva na entrega das espadas aos novos guardas-marinha. Ele está rígido, inclinado para a frente, como se fosse cair. Na outra, uma cena deslocada no tempo, com a seguinte legenda: "Garrincha foi expulso quando o Brasil vencia o Chile na Copa de 62”. Pela primeira vez, no lugar dos editoriais, eram publicadas duas fotos: na maior, um lutador de judô, gigante, dominando um garoto. O título da foto: "Força hercúlea" (VenturA, 1988, p. 288-289).

Para os militares, a ação denunciatória da imprensa era um empecilho à utilização de um dos seus mais frequentes métodos de interrogatório e repressão: a tortura. Esta não era vista como um mal em si, pelo teor de atrocidade e sadismo que encerra, mas a divulgação de sua prática para o grande público representava uma

\footnotetext{
2 Disponível em: https://bit.ly/2LkTQXM. Acesso em: 19 jun. 2013.
} 
nódoa na imagem populista de pai zeloso de que o regime se investiu. Segundo Elio Gaspari:

Geisel também estabeleceu a relação entre tortura e defesa do regime, vendo a essência do problema nas denúncias da imprensa, e não no que se denunciava: "Essa imprensa nunca teve interesse em dizer a verdade. Quando muito, apresentava de forma para ela conveniente, a meia verdade. Havia o deliberado interesse de torcer, deturpar ou exagerar os fatos conforme a conveniência" (GASPARI, 2003, p. 149). ${ }^{3}$

É curioso notar que, nos anos 1970, a pressão sobre Chico Buarque era tão grande que ele já não tinha nenhuma música autorizada pela censura para gravar. Tudo o que ele enviava para apreciação levava meses para ser autorizado e, ainda assim, sempre com muitas ressalvas e "sugestões" de modificação. Foi nesse período que ele passou a enviar músicas assinadas com o pseudônimo de Julinho da Adelaide, e todas foram autorizadas. Em 1974, ele grava o disco Sinal fechado, somente com músicas de outros compositores (incluindo duas do seu pseudônimo, Julinho da Adelaide).

No entanto, impossibilitado de gravar as próprias canções, Chico Buarque publica, no mesmo ano, Fazenda Modelo: novela pecuária, e, ironia imensa e denúncia escandalosa da arbitrariedade da censura, o livro, uma sátira ao regime, mantémse, nos anos de 1974 e 1975, em primeiro lugar nas listas dos mais vendidos da Revista Veja. Sandra Reimão (2011, p. 63), em pesquisa aos arquivos dessa revista, informa ainda que a classificação de Fazenda Modelo foi melhor até do que a de $G a$ briela, cravo e canela, de Jorge Amado (sempre recordista de vendas com os romances anteriores, de cunho social), e do que a edição revisada naquele ano do $\mathrm{Di}$ cionário Aurélio. Em 1976, o nome de Chico Buarque volta a encabeçar a lista dos mais vendidos, desta vez em parceria com Paulo Pontes, com o livro Gota d'água, roteiro da peça teatral homônima, cuja montagem fora interditada pela censura naquele mesmo ano. A popularidade dessas duas obras poderia ter vestígios da empatia de Chico Buarque, o compositor, com o público, mas o fato de se tratar de textos que contestavam a situação sócio-política do país naqueles anos de chumbo é sintomático de que o povo já não se iludia com o rescaldo do tricampeonato de futebol e nem com as promessas não cumpridas do milagre econômico brasileiro.

A publicação de Fazenda Modelo se apresentou, naquele contexto, não apenas como a primeira incursão literária de Chico Buarque, mas como um imperativo político de um autor engajado, militante da democracia, que fez de sua arte um instrumento para a enunciação dos discursos silenciados pelo regime.

3 Os militares nunca admitiram que a tortura fosse uma prática corrente nos porões dos seus quartéis. Mesmo atualmente, apesar de todas as evidências e provas coletadas e divulgadas por grupos como o Tortura Nunca Mais e pela Comissão da Verdade, muitos militares reformados afirmam que as denúncias de torturas e assassinatos são calúnias. 
No enredo paródico que Fazenda Modelo encena, a narrativa se monta em associações imagéticas, que incluem ilustrações, para compor um mosaico de linguagens que preenchem semanticamente o texto. A apropriação de signos de outras artes que a narrativa engendra aproxima-se de uma das definições de paródia propostas por Linda Hutcheon em Uma teoria da paródia: "é um processo integrado de modelação estrutural, de revisão, reexecução, inversão e 'transcontextualização' de obras de arte anteriores" (Hutcheon, 1989, p. 22). Não se trata de influência ou imitação de predecessores, mas de uma canibalização consciente, muito mais criativa que alusiva, e marcada pelo que Hutcheon (1989, p. 22) chama de "inversão irônica", ou seja, de um embate estilístico que instaura a diferença no espaço da semelhança.

Nesse processo de "transcontextualização", códigos múltiplos são associados na composição narrativa. Em Fazenda Modelo, mapas, gravuras e notícias de jornal são combinados à descrição cinematográfica de imagens, numa paródia de manual acadêmico que se utiliza de exemplos e ilustrações para comprovar a sua tese: a ordem e a disciplina seriam as únicas chances de desenvolvimento nacional (mote do contexto histórico). Seguindo o fluxo temporal da narrativa, não apenas na contextualização histórica, mas no próprio tempo de narratividade, como se o enredo também se sucedesse linha a linha, sem previsão de como se concluirão as ações descritas, o desfecho aponta para o fracasso da empreitada modernizadora da Fazenda Modelo. $\mathrm{O}$ último ato do enredo é marcado pela reversão irônica - peculiar da paródia - que dizima todos os membros da fazenda, por terem se mostrado improdutivos e indomáveis, e os substitui pelo cultivo de soja, mais seguro e rentável.

As atrocidades do cotidiano real da tortura, transformada em instrumento de governo nos anos da ditadura, são hiperbolizadas na narrativa, como na descrição do sadismo do torturador, representado, na novela, pelo responsável pela ferra, que extrapola das suas atribuições empolgado pela arbitrariedade do poder que detém ao ponto de acreditar conferir ao seu trabalho um valor estético, devido ao primor com que desempenhava a sua função:

O artesão Karim, encarregado da ferra, era o mais inspirado. Não satisfeito com a simples impressão das iniciais da Fazenda (FM), tatuava as letras nas mais formidáveis combinações, até que as carcaças ficassem lembrando um mosaico:

A imagem do boi completamente marcado (Figura 2) pode ser lida como o apuro do sadismo da tortura. O boi não deve ser morto, pois é necessário como mão de obra manipulável. Ele é o instrumento pelo qual o torturador desempenha o seu trabalho, como um burocrata do sistema, e tal imagem estampada em $\mathrm{Fa}$ zenda Modelo antecipa a reflexão feita por Flávio Tavares, aproximadamente trinta anos depois, em suas memórias: "Eles não são assassinos, apenas torturadores, o estágio mais alto do sadismo. Torturar é a dinâmica desse purgatório perene, onde tudo se sofre e nada se purga" (TAVARES, 2012, p. 29). A tortura é o momento em 


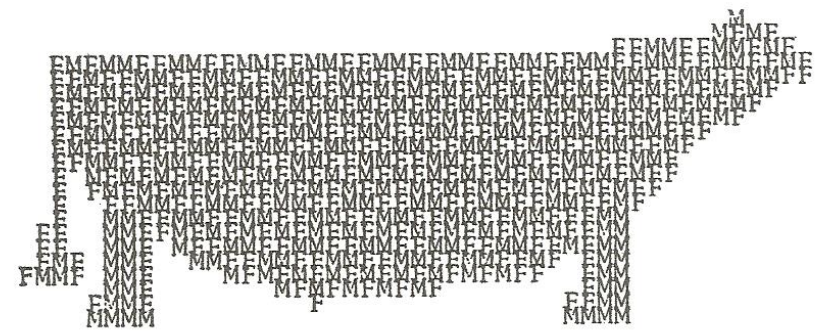

Fig. 2 - Boi marcado a ferro. Fonte: Buarque (2006, p. 22).

que a arbitrariedade do poder atinge o ápice da crueldade, pois é quando o preso, covardemente subjugado, tem sua vida à mercê do poder que um outro adquire violentamente sobre o seu corpo e espírito. Mesmo o sadismo dispõe de método para ser mais eficiente no aniquilamento do torturado, como descreve Tavares sobre o uso do choque elétrico:

Poupa-se o coração: não se tortura pelo lado esquerdo e o máximo que avançam aqueles fios de cobre é até o meio do corpo, na virilha, no pênis ou no ânus. Ou então no centro do corpo, na cabeça, e aí os fios se espalham por todos os lados, das têmporas à nuca, da nuca ao nariz, das narinas às orelhas e ao fundo dos ouvidos. Ou, então, o torturador se deleita roçando suavemente os fios elétricos sobre nossos olhos e a vista queima, arde de calor, porque - mesmo fechados - os olhos continuam abertos de dentro para fora, espreitando esse tigre metálico que leva fogo à retina (TAVAREs, 2012, p. 30, grifo nosso).

A ironia do deleite que associa a ideia de suavidade a um gesto de violência é similar ao prazer estético do torturador ao ver sua obra-prima de estamparia marcada à brasa no corpo do que estão subjugados a sua vontade. A imagem do boi ferrado pode ser lida como um questionamento estético do horror, mas sua inserção na estrutura textual de Fazenda Modelo, para além da finalidade ilustrativa, pode ser entendida também como uma apropriação de um importante referente artístico desde o início dos anos 1960: a poesia concreta.

Nos poemas concretos a palavra assume o papel de signo e símbolo e instrumentaliza o poeta, que a utiliza também para uma nova configuração formal do seu texto, como no famoso poema Lixo (1965), de Augusto de Campos, em que a palavra luxo é repetida e ordenada para compor, em letras maiores, a inscrição lixo. A representação logocêntrica converte-se em inscrição icônica, que infere uma interpretação do leitor, obrigando-o a questionar os sentidos textuais ampliados para além do aparente pela palavra tornada ícone.

A opção de usar a ironia para romper com o automatismo das interpretações se mostra como possibilidade ética de falar do proibido a partir da combinação entre alegoria e paródia. A ironia possui um sentido político, no sentido mais amplo 
dessa palavra, pois se insere em uma cena que, conforme afirma Linda Hutcheon (200o, p. 17), "envolve relações de poder baseadas em relações de comunicação. Inevitavelmente ela envolve tópicos sensíveis tais como exclusão e inclusão, intervenção e evasão". Para compor uma estrutura comunicativa e política, em Fazenda Modelo, a narrativa se apropria de elementos que estão além da literatura e compõe seu mosaico de palavras e imagens. Além da canibalização da poesia concreta, a própria condição da imprensa, amordaçada pela ditadura, é denunciada pela inserção irônica de uma página de jornal, fictícia, mas nos moldes das notícias de propaganda ao regime que a imprensa publicava, em apoio ou por imposição.

A ironia da notícia elogiosa inserida no texto assume caráter de oposição, no sentido que Linda Hutcheon pensa as funcionalidades da ironia. Ela ressalta a classificação "de oposição" como a mais utilizada nos contextos políticos de maior fechamento, como as ditaduras, pois as "arestas" da ironia ferem de todos os lados, assumindo caráter contestador, mas também um risco para quem a utiliza, já que seus efeitos pragmáticos também se opõem. Como a interpretação do leitor tem papel fundamental na compreensão e mesmo na criação dos sentidos do texto, o que uns leem como transgressão, outros interpretam como insulto; o que para uns é subversão, para outros é apenas ofensa. Em todo o caso, para além da intenção do enunciador, o discurso irônico opera como "mina-de-dentro do politicamente reprimido", como analisa Hutcheon (2000, p. 83), que afirma ainda:

Para aqueles posicionados dentro de uma ideologia dominante, essa contestação pode ser vista como abusiva ou ameaçadora; para aqueles marginalizados e que trabalham para desfazer aquela dominação, ela pode ser subversiva ou transgressora, nos sentidos mais novos, positivos, que essas palavras tomaram em textos recentes sobre gênero, raça, classe e sexualidade.

A notícia relata a inauguração de um bebedouro popular, de nome Keitel, mas popularmente conhecido como Panelão, situado ao norte da Fazenda e ligado ao controle e vigilância do bebedouro central. A linguagem do governo não fala ao povo, que adapta e renomeia suas obras conforme seu entendimento, e todos vão beber água no Panelão. Na solenidade, o povo canta a marcha "Viva Fazenda", agitando flâmulas. As crianças do grupo escolar repetem a canção depois de cortadas as fitas. O governo, suas ações e agentes destacam-se na matéria por suas iniciais em K, desde as propagandas comerciais do Coagulante Kapp, da motosserra portátil KKKK ou da loja de materiais de construção Kulmaco, até o nome do grupo escolar K. Kramer e seu maestro Karim. Pode parecer uma extrapolação, mas é inevitável recordar da atuação do grupo racista americano Ku Klux Klan, nascido no final do século XIX e vigente, sob vários comandos e administração de várias entidades até meados dos anos 196o. Os grupos que se abrigavam sob a sigla KKK com a qual marcavam a testa de suas vítimas ficaram famosos pela prática de linchamentos, coerções, tortura e assassinatos, a princípio contra negros e depois contra judeus, homossexuais, prostitutas e diversos grupos minoritários. 
A incomunicabilidade entre povo e governo se destaca na ironia dos nomes. O povo aplaude o progresso, mas é preciso que Juvenal fale em sua linguagem para que o recado seja entendido "Boi ligeiro bebe água, boi romeiro bebe lama" (BuARQue, 2006, p. 65), e, a despeito das dimensões do tanque e da sede, a denúncia escapa na entrelinha da demagogia: "os bois colocaram-se em fila indiana, sendo que, mesmo sedentos, ninguém quis ser o primeiro da fila” (BuARQUE, 2006, p. 65). Vão em romaria, beber a lama presenteada com pão e circo pelo seu magarefe.
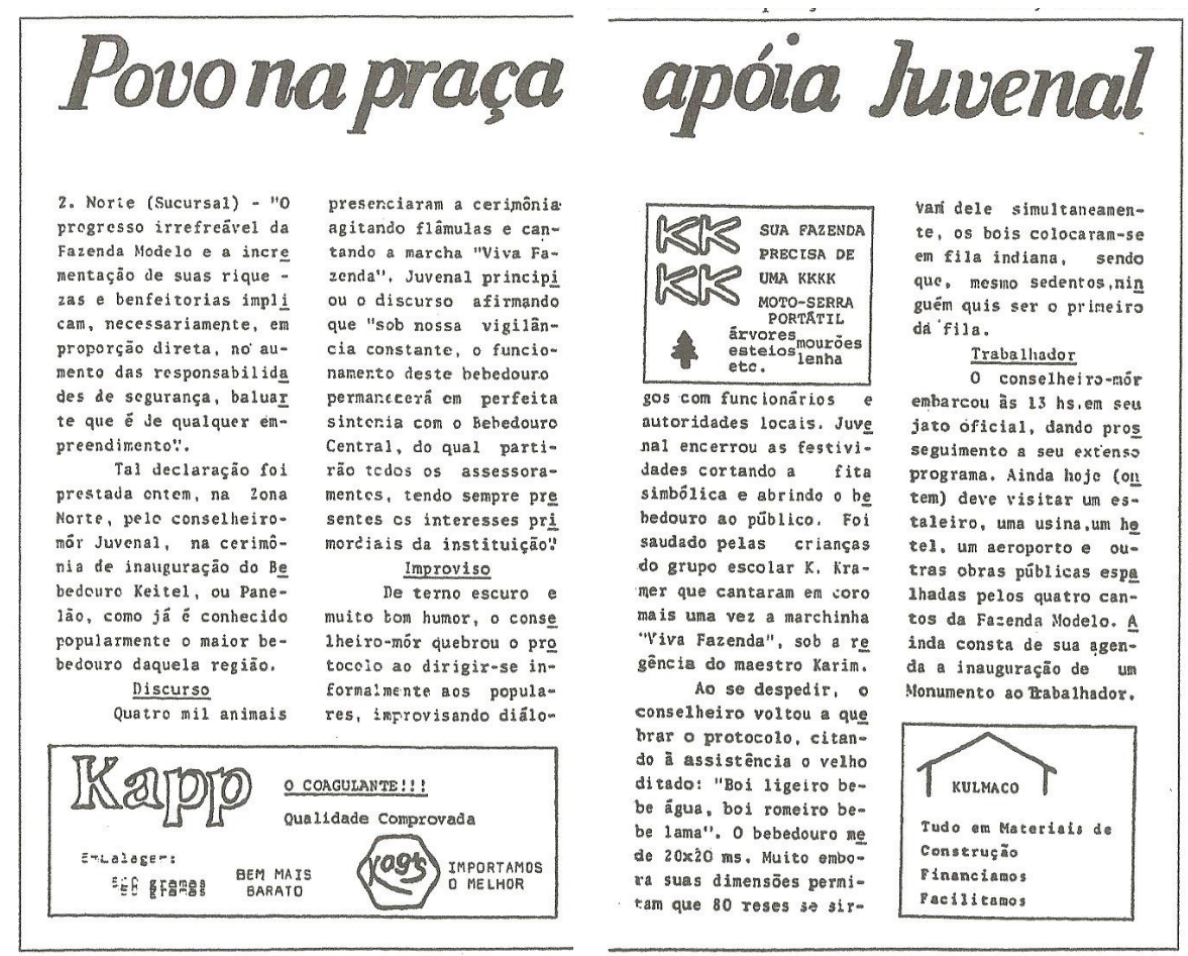

Fig. 3 - Notícia de jornal. Fonte: Buarque (2006, p. 64-65).4

A notícia de jornal (FigurA 3) é uma versão resumida dos fatos narrados no capítulo $\mathrm{X}$, intitulado "O povo na praça". O povo dos descampados, gente rude que sustenta o progresso com o trabalho pesado, é apresentado, nesse capítulo, como massa bestializada, não apenas pela condição irônica - e icônica - de gado, mas pela conduta social disciplinada por meios sensíveis que induzem a um padrão de comportamento mantenedor do status quo. O povo dos descampados é massa-

4 Tanto na $17^{\mathrm{a}}$ edição, utilizada neste artigo, quanto na primeira, também consultada, a notícia destacada ocupa duas páginas, entremeada ao texto. Não parece que essa disposição seja apenas uma opção gráfica, para compor a organização física do livro, mas, sim, uma estratégia paródica, que destaca, como nos jornais, as notícias importantes em matérias de capa que ocupam muitas páginas no corpo do jornal. O recorte e a montagem foram feitos por mim para facilitar a visualização neste artigo, atendendo à questão de organização do texto, mas assumindo o risco de com isso violar, talvez, os sentidos possíveis que a distribuição em duas páginas permite à formatação original. 
crado por um regime que se apropria da sua força produtiva, mas não percebe sua condição graças a estratégias que permitem o extravasamento do que é reprimido no seu cotidiano de subalternidade. O mesmo regime que ferra e mutila dá a festa e refreia protestos com falsas homenagens, como o monumento ao trabalhador, mote do capítulo e da notícia jornalística. Trata-se de uma estátua que representa a figura do bom trabalhador da Fazenda Modelo, um afago de Juvenal, o Bom, para manter o gado encangado. Quem a descreve é o personagem do patrão, com o deslumbramento de quem se sente agraciado pelo poder daquele que se coloca na posição paternal de governante justo:

Anatomia: tipo muscular, pele grossa, cabeça curta, orelhas grandes e felpudas, o colo carnoso, espáduas grossas e largas, as cruzes salientes, o espinhaço forte e breve, a papada pendente até o joelho, joelhos sólidos e cilíndricos, jarretes sãos, as articulações íntegras, amplas ancas os pés no chão, sinais particulares distribuídos pela carcaça. E eu só queria ter a minha Anaía ali perto para dizer se o Trabalhador era ou não era a minha cara, em tamanho maior. Benzam-me a boca se não parece até que fui eu que posei para aquela escultura (BUARQUE, 2006, p. 66-67).

A descrição minuciosa do "Monumento ao Trabalhador" permite ao leitor a criação de uma imagem mental de um objeto, mas, para além disso, desvela um mecanismo de controle, que promove uma identificação do sujeito com um símbolo que o faz aparentemente destacado da massa, quando, na verdade, sua representação acaba reforçando esta condição. Provavelmente todos os trabalhadores, os "mais de quatro mil animais" de que fala a notícia do jornal, sentiram-se particularmente representados e homenageados por aquela estátua, irradiando um sentimento de utilidade pública e reconhecimento social que oculta o controle a que estão submetidos. A notícia do jornal, em que a violência do Estado se insinua, apesar das tentativas de ocultação, representa a irradiação do controle para toda uma comunidade, sob a forma de sociabilidade midiática, em que o real se transfigura naquilo que interessa a um determinado grupo. Como afirma Muniz Sodré, em Sociedade, mídia e violência:

A sociabilidade implicada no modelo de midiatização tem mais a ver com "massa" enquanto metáfora explicativa de uma ontologia relacional precária do que com "multidão", esta entidade que pode ser descrita como "cadeia humana", suscetível de identificações e emoções profundas, capaz de uma vontade de ação na História. Por outro lado, o indivíduo com identidade fixa e a multidão fazem possíveis os contatos encadeados ou contagiantes (daí, a "epidemia"), que os expõe uns aos outros, não apenas à concretude interpessoal, mas também à partilha de uma regra comunitária: a circulação da violência, ritualística ou anômica, dá-se nesse contexto simbólico (SODRÉ, 2006, p. 31).

Nesses fragmentos de história reconstruídos alegoricamente, unem-se recursos narrativos que servem tanto para dar uma visibilidade imagética quanto o teor 
irônico do discurso, aquilo que Linda Hutcheon denomina como marcadores textuais da ironia (compreendendo texto como mais além da palavra escrita). Esses marcadores são sinais que indicam ao leitor/espectador a presença de uma intenção irônica a ser interpretada e podem ser classificados em gesticulatórios (como o movimento que o falante faz de levantar as mãos e movimentar dois dedos para dar a entender que determinada palavra ou expressão estaria entre aspas), fônicos (como a entonação, o ruído de limpar a garganta ou mesmo de riso simulado) e gráficos (os mais difíceis de enquadrar já que dependem do contexto e do leitor, que interpreta no texto a presença de exclamações, parênteses, itálicos etc.). $\mathrm{Na}$ citação anterior, em exposição inversa, o marcador gráfico está representado pela reprodução do dito popular, revertido ironicamente pelo marcador gestual do tapinha nas costas e pelo marcador fônico do sorriso mal contido que arremata a representação das relações de poder: "ninguém mais berra".

Mas berra. E naqueles anos de 1970, muitas vozes, primeiro sussurradas, depois berradas mesmo, foram se fazendo ouvir apesar de todas as tentativas de silenciamento. Não é à toa que o décimo segundo capítulo de Fazenda Modelo, intitulado "Inseminário", começa com o grito das mães em busca de notícias sobre os seus filhos, afastados de seu convívio pelo "bem" da fazenda. Logo no primeiro parágrafo, o jogo de palavras com a expressão "rabo" a partir de trocadilhos com ditados populares descreve um momento de lucidez das vacas da fazenda, que já não se deixam iludir pelas promessas milagreiras de um Juvenal de quem já duvidam:

Há rabo entre as pernas, rabo eriçado, rabo à inglesa, rabo torcido, rabo de palha, rabo bifurcado, rabo tridentado, rabo abanando e é pelo rabo que o entendido julga uma vaca, seu estado de ânimo. Por isso Juvenal recuou dois passos quando a tropa de vacas invadiu a Estância, Aurora cabo com seu rabo de foguete [...]. Ser mãe.

- Quero meu filho! Quero Lustroso! Quero Lindaci! (BuARQue, 2006, p. 75).

Juvenal as convida para um passeio, a fim de arejar e esquecer da preocupação com os filhos desaparecidos: "Vamos, queridas, está tudo bem, as crianças, a Fazenda, vocês não querem dar uma volta comigo? Arejar, que tal a Jungla?" (BUARQUe, 2006, p. 75).

Neste ponto do enredo de Fazenda Modelo, desvelam-se as memórias de duas situações distintas daquele momento histórico, que o livro testemunha ficcionalmente em sua narrativa. De um lado, os familiares dos desaparecidos começavam a exigir explicações, de outro, o governo continuava o seu intento de apaziguar as críticas com obras faraônicas, que empolgavam a população e atraíam investidores, como a construção da rodovia Transamazônica.

No primeiro caso, uma situação específica, mas representativa da realidade de centenas de outras famílias brasileiras, é a história de Zuleica Angel Jones, a estilista Zuzu Angel, mãe de Stuart Edgar Angel Jones. Stuart foi um dos líderes da 
organização revolucionária MR-8, morto em 14 de junho de 1971, com requintes de sadismo, nas dependências do Centro de Informações e Segurança da Aeronáutica (Cisa), quando foi amarrado à traseira de um jipe oficial com a boca próxima ao cano da descarga. Desde a prisão de Stuart, em 1971, Zuzu aproveitou-se da sua notoriedade enquanto estilista reconhecida internacionalmente para procurar pelo corpo de seu filho e exigir a confirmação de sua morte por tortura.

No momento da publicação de Fazenda Modelo, essas buscas ainda não tinham a seu favor a carta-denúncia feita por Alex Polari de Alverga, ${ }^{5}$ preso pouco antes de Stuart, seu delator e testemunha de sua morte, mas já mobilizavam artistas, inclusive fora do país, como Joan Crawford, Kim Novak e Liza Minelli, para a denúncia de crimes bárbaros cometidos pelo governo militar brasileiro. A violência do estado atingia, finalmente, a classe média, que passou a questionar os métodos do sistema que apoiara, o que se desvela ficcionalmente nas palavras de Juvenal:

E já avistava a Estância quando as vaquinhas retomaram a cantilena do cadê meu filho. Aí Juvenal perdeu a cabeça e disse uma verdade. Disse que naquela fazenda, crimes, sumiços e barbaridades sempre houve e ninguém nunca se importou com isso. Agora as vaquinhas estão chocadas porque pode acontecer a seus filhos o que antes só acontecia ao filho da empregada.

- Bruto assassino!

- Assassino cínico! (BuArque, 2006, p. 77).

Parodiando as publicações da época, a novela de Chico Buarque também apresenta imagens que ilustram o progresso da Fazenda Modelo, tanto na ma-

5 A luta de Zuzu Angel para reaver o corpo do filho assassinado foi reforçada em 1975, quando a carta escrita ainda na cadeia por Alex Polari de Alverga finalmente chegou às suas mãos. A partir daí, Zuzu criou o "Dossiê Stuart", que divulgou a todas as autoridades possíveis, incomodando o regime e se expondo. Passou a sofrer ameaças e, na noite anterior a sua morte, deixou na casa de Chico Buarque um bilhete informando sobre as perseguições sofridas. Ela morreu em 14 de abril de 1976, num acidente de automóvel suspeito. Em 1998 a Comissão Especial de Mortos e Desaparecidos da Secretaria de Direitos Humanos da Presidência da República reconheceu a responsabilidade do Estado na morte de Zuzu Angel. Mais informações a seu respeito podem ser obtidas na internet, no site oficial do Instituto Zuzu Angel (http://www.zuzuangel.com.br/html/ instituto.asp), fundado por sua filha Hildegard Angel, e na página do Grupo Tortura Nunca Mais (http://www.torturanuncamais-rj.org.br), entre outras. Em 2006, a biografia de Zuzu Angel inspirou o filme que leva seu nome, dirigido pelo cineasta Sérgio Rezende e protagonizado por Patrícia Pillar. Na biografia Chico Buarque - Para todos, para a coleção Perfis do Rio, Regina Zappa (1999) inclui um fac-símile do bilhete que Zuzu Angel escreveu para Chico Buarque. No livro Mulheres que foram à luta armada (1998, p. 410-412), Luiz Maklouf Carvalho dedica um capítulo a Zuzu Angel e sua nora, Sônia Angel, também presa, torturada e assassinada em novembro de 1993, por militares do Exército Brasileiro. Seus pais empreenderam batalha semelhante à de Zuzu para descobrir o paradeiro do corpo da filha, só localizado em 1991. Em 1994, o tenente-coronel da reserva João Luiz de Moraes publica com recursos próprios o livro O calvário de Sônia Angel: uma história de terror na ditadura, em que conta, depois de anos de investigações, as atrocidades cometidas pelos militares que prenderam, torturaram, mutilaram sua filha até a morte. 
téria de jornal já analisada, como na presença dos mapas reproduzidos a seguir (Figuras 4 E 5):

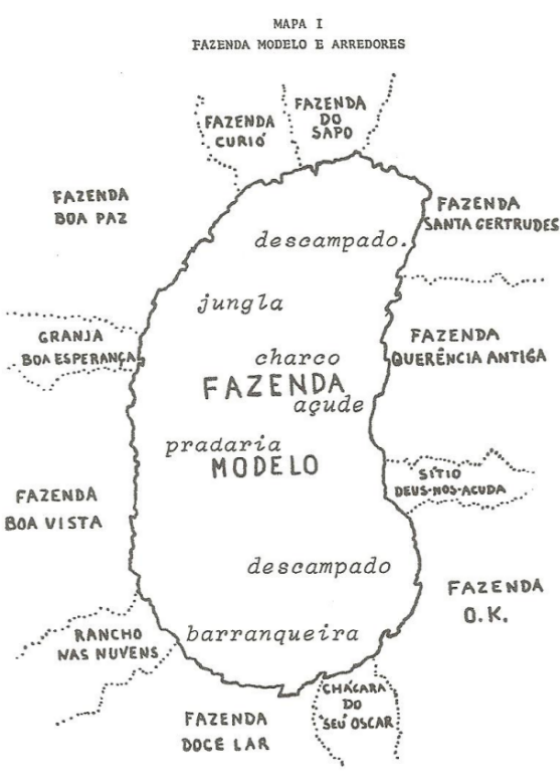

Fig. 4 - Antes de Juvenal. Fonte: Buarque (2006, p. 18).

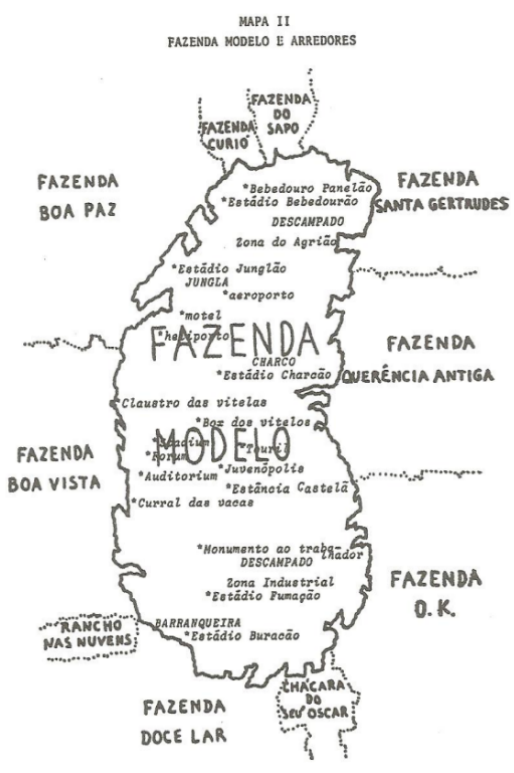

Fig. 5 - Depois de Juvenal. Fonte: Buarque (2006, p. 82)

De acordo com os mapas, um de antes do governo de Juvenal e o outro do auge da sua administração (este inserido ao final do capítulo em que a transformação da Jungla é o tema principal), as fronteiras da Fazenda Modelo permanecem as mesmas, a despeito do novo traçado. Contudo, sua configuração geopolítica sofre alterações radicais. O que antes era formado por vastos territórios improdutivos ("descampado", "jungla", "charco", "açude", "pradaria", "descampado", "barranqueira") assumiu contornos e nomenclaturas condizentes com a nova conjuntura da Fazenda. As principais mudanças referem-se à região centro-sul, onde foi implantada toda a estrutura administrativa e produtiva: "estância Castelã", "Fórum", "Auditorium", "Box dos vitelos", "Claustro das vitelas", "Curral das vacas", "Touril", "Juvenopólis" e "Stadium".

A ironia insinua-se nos mapas não apenas nos novos nomes, incluindo o autoelogio tão comum aos políticos de nomear cidades em sua própria homenagem, mas em sua expressão gráfica, na imitação de termos latinos, como a dar ainda mais autoridade às instâncias administrativas. A distinção do tratamento que recebem governantes e subordinados fica marcada sutilmente também na diferença entre o "Stadium" central e os vários estádios periféricos, cujos nomes no aumentativo exacerbam o sentido de construção popular. "Bebedourão", "Junglão" (com a "Zona do Agrião" entre um e outro), "Charcão", "Fumação" (ao lado da "Zona Industrial" e do "Monumento do Trabalhador", no descampado) e Buracão são as principais construções fora do centro administrativo, reforçando a política de con- 
trole por meio de símbolos de nacionalidade, como o futebol. Nos mapas ainda é reservado espaço para uma intromissão do autor, admirador declarado e amigo do renomado arquiteto Oscar Niemayer, na presença da "Chácara do Seu Oscar".

A inserção de imagens-figuras na narrativa suplementa os sentidos das imagens sugeridas pela linguagem literária, pois, como afirma Octavio Paz, ela tem a capacidade de forçar o leitor a reviver uma experiência do real, já que desperta, recria, evoca, ressuscita, enfim, apresenta, mais do que representa, essas experiências. Segundo Paz:

Toda frase quer dizer algo que pode ser dito ou explicado por outra frase. Em consequência, o sentido ou significado é um querer dizer. Ou seja: um dizer que pode dizer-se de outra maneira. O sentido da imagem, pelo contrário, é a própria imagem: não se pode dizer com outras palavras. A imagem explica-se a si mesma. Nada, exceto ela, pode dizer o que quer dizer. Sentido e imagem são a mesma coisa (PAZ, 2005, p. 47).

Fazenda Modelo é uma narrativa híbrida, entre a novela e o romance, texto literário que canibaliza a linguagem cinematográfica e, assim, visibiliza fragmentos de uma história coletiva na consciência, também coletiva, tanto daqueles que viviam aquela conjuntura histórica como dos que só souberam dela tempos depois. Talvez pelo forte aspecto testemunhal, Fazenda Modelo foi considerada por muito tempo como um texto à parte no conjunto da obra de Chico Buarque. Contudo, como se tentou mostrar neste artigo, trata-se de uma narrativa que já antecipa traços estruturais, de estilo e mesmo de tema, embora de forma um tanto enviesada, indireta.

O hibridismo entre linguagem literária e cinematográfica, através de imagens montadas no texto como fotogramas de cinema, o posicionamento político diante da história, o memorialismo (coletivo ou individual) - anticonvencional em sua estrutura, como estratégia de escrita, são traços que se desenvolverão nas obras mais maduras do autor, mas que já se antecipam nessa "novela pecuária". Ela apresenta uma costura de alegoria e paródia para romper o silêncio e tornar-se resistência, instrumento político de um intelectual engajado (que ironiza, inclusive, esta condição), e arremata essa estratégia com o uso de recursos irônicos que colocam o leitor numa posição participativa - sem que para isso o autor morra! -, como na ironia final, em que o autor se ficcionaliza na figura de um narrador intruso, no longo parágrafo que forma o Ato final:

Por meio de um ofício bastante complicado, como que encabulado, cheio de acidentes gramaticais, acentos agudos, crases ameaçadoras, reticências, parêntesis e/ou hifens, aspas e mais vírgulas, sempre separando sujeito e verbo, como se aquele sujeito não fizesse questão de assumir o seu verbo, e, através de um ato desses, que eu não gostaria de incluir aqui, mesmo porque está dando praia, e eu não tenho nada com isso, isso é novela, é só bestialógico, então Juvenal mandou liquidar o gado restante, ele compreendido, decretando o fim da experiência pecuária, na Fazenda Modelo, 
e destinando os seus pastos, a partir deste momento histórico, à plantação de gado tão-somente, porque resulta mais barato, mais tratável e contém mais proteína (BUARQUE, 2006, p. 117, grifo nosso).

Novela que parodia manuais acadêmicos, livros de história, jornais e revista; bestialógico que se reveste de engajamento, mesmo em dia de praia, Fazenda Modelo parte do grotesco e do absurdo para propor uma mise en abyme reflexiva que desencava do esquecimento "memórias de um tempo em que lutar por seus direitos é um defeito que mata". ${ }^{6} \mathrm{O}$ tempo da história é cíclico: qualquer semelhança com o Brasil contemporâneo não é mera coincidência.

\section{Referências}

BuAroue, Chico. Fazenda Modelo: novela pecuária. 17. ed. Rio de Janeiro: Civilização Brasileira, 2006.

CArvalho, Luiz Maklouf. Mulheres que foram à luta armada. São Paulo: Globo, 1998.

Duarte, Lélia Parreira. Ironia e humor na literatura. Belo Horizonte: Editora da PUC-Minas; São Paulo: Alameda, 2006.

Gaspari, Elio. A ditadura derrotada: as ilusões armadas. São Paulo: Companhia das Letras, 2003.

Grupo Tortura Nunca Mais - RJ. Disponível em: http://www. torturanuncamais-rj.org.br. Vários acessos.

Grupo Tortura Nunca Mais - SP. Disponível em: http://www. torturanuncamais-sp.org. Vários acessos.

Hutcheon, Linda. Uma teoria da paródia: ensinamentos das formas de arte no século XX. Tradução de Teresa Louro Pérez. Lisboa: Edições 70, 1989.

Hutcheon, Linda. Teoria e política da ironia. Tradução de Júlio Jeha. Belo Horizonte: Editora da UFMG, 2000.

Mota, Carlos Guilherme. Ideologia da cultura brasileira (1993-1974): pontos de partida para uma revisão histórica. 3. ed. São Paulo: Ed. 34, 2008.

PAz, Octavio. O arco e a lira. Tradução de Olga Savary. 2. ed. Rio de Janeiro: Nova Fronteira, 1982.

Reımão, Sandra. Repressão e resistência: censura a livros na ditadura militar. São Paulo: Edusp/Fapesp, 2011.

\footnotetext{
6 Trecho da canção "Pequena memória para um tempo sem memórias (A legião dos esquecidos)", de Gonzaguinha, parte do álbum A vida do viajante - Luís Gonzaga e Gonzaguinha. 1981. EMIOdeon.
} 
Sodré, Muniz. As estratégias sensíveis: afeto, mídia e política. Petrópolis: Vozes, 2006.

Tavares, Flávio. Memórias do esquecimento: os segredos dos porões da ditadura. Ed. amp. Porto Alegre: L\&PM, 2012.

Ventura, Zuenir. 1968, o ano que não terminou. Rio de Janeiro: Nova Fronteira, 1988.

ZAPPA, Regina. Chico Buarque: para todos. Rio de Janeiro: Relume Dumará, 1999.

Recebido em 9 de junho de 2017.

Aprovado em 25 de março de 2018.

\section{Resumo/Abstract/Resumen}

Imagens e palavras no tecido de memórias tortuosas: Fazenda Modelo: novela pecuária em tempos de golpe

\section{Mírian Sumica Carneiro Reis}

O presente artigo propõe uma leitura de Fazenda Modelo: novela pecuária, publicada em 1974 por Chico Buarque. O contexto da publicação, durante o período de ditadura civil-militar no Brasil, é considerado como fato preponderante para uma narrativa escrita alegoricamente a fim de denunciar o estado de exceção instalado no país. Deste modo, este artigo se debruça sobre as estratégias discursivas baseadas na ironia e na paródia que irão compor uma narrativa que se constrói também como memória de um tempo que não pode ser esquecido.

Palavras-chave: ditadura, memória, literatura, Chico Buarque, Fazenda Modelo.

\section{Images and words in tortuous memory fabric: Fazenda Modelo: novela pecuária in times of military coup}

\section{Mírian Sumica Carneiro Reis}

This article proposes a reading of Fazenda Modelo: novela pecuária (Model Farm: rural novel), published in 1974 by Chico Buarque. The context of its publication - the period of civil-military dictatorship in Brazil - is considered an imperative fact for a narrative whose text was written allegorically in order to report the state of exception which the country was under. Therefore, this article focuses on discursive strategies based on irony and parody, in the stages of composing said narrative which, in turn, writes itself as a recollection of a time that cannot be forgotten. 
Keywords: dictatorship, memory, literature, Chico Buarque, Fazenda Modelo.

Imágenes y palabras en el tejido de memorias tortuosas: Fazenda Modelo: novela pecuária en tiempos de golpe

\section{Mírian Sumica Carneiro Reis}

Este artículo propone una lectura de Fazenda Modelo: novela pecuária (Granja Modelo: novela pecuaria), publicada en 1974 por Chico Buarque. El contexto de la publicación, durante el período de dictadura civil-militar en Brasil, es considerado como un hecho preponderante para una narrativa escrita alegóricamente con la finalidad de denunciar el estado de excepción instalado en el país. Así, este artículo se centra en las estrategias discursivas basadas en la ironía y la parodia, que componen una narrativa que también se construye como memoria de un tiempo que no puede ser olvidado.

Palabras clave: dictadura, memoria, literatura, Chico Buarque, Fazenda Modelo. 